\title{
Insulin Receptor Number and Binding Affinity in Newborn Dogs ${ }^{1}$
}

\author{
VICKI JOHNSTON, VINCENT FRAZZINI, SANDRA DAVIDHEISER, RONALD J, PRZYBYLSKI, \\ AND ROBERT M. KLIEGMAN \\ Departments of Pediatrics, Anatomy, and Reproductive Biology, Case Western Reserve University School of \\ Medicine and Rainbow Babies and Childrens Hospital, Cleveland, Ohio 44106
}

\begin{abstract}
The insulin resistance in newborn mammals may be caused by a receptor or postreceptor defect. Although liver and umbilical cord blood monocytes have increased numbers of insulin receptors, there is a paucity of information about other neonatal tissues. Glucose disposal takes place primarily in the skeletal muscle; therefore, it is important to evaluate this tissue for an insulin receptor defect. To determine the role of insulin receptors in neonatal insulin resistance, neonatal and adult canine skeletal muscle, heart, and liver were compared for numbers of insulin receptors and their affinity for insulin. Partially purified receptors from four animals in each group were obtained by wheat germ lectin affinity chromatography and used in competition binding studies. Specific binding (mean $\pm \mathrm{SE}$ ) in the absence of cold insulin was increased in newborn skeletal muscle $(9.7 \pm 0.8$ versus $4.8 \pm 0.5 \%, p<0.001)$ and heart $(8.1 \pm 1.2$ versus $5.5 \pm$ $0.6 \%, p<0.05$ ). High-affinity insulin receptor number (mean \pm SEM) was increased in newborn skeletal muscle $(183 \pm 40$ versus $120 \pm 29 \mathrm{pM}, p<0.002)$ and heart $(264$ \pm 94 versus $157 \pm 51 \mathrm{pM}, p<0.05$ ) as estimated from the $X$ intercept of the Scatchard plot. Using half-maximal binding to estimate affinity, there were no differences between adults and newborns among all tissues studied. High-affinity receptor number and percentage of specific binding were similar for newborn and adult liver tissue. No binding defect was found, as depicted by the observations that the affinity was the same and the number of insulin receptors was the same or increased in the tissues of the newborn compared to the adult dogs. These results provide evidence that newborn insulin resistance may be caused by a postbinding defect. (Pediatr Res 29: 611-614, 1991)
\end{abstract}

Abbreviations

HEPES, $N$-2-hydroxyethylpiperazine- $N$ '-2-ethanesulfonic acid

Studies in animals (1) and infants $(2,3)$ have suggested that the glucose intolerance of newborn infants is secondary to insulin resistance. Although the cellular basis of insulin resistance is unknown, it may result from a binding or a postbinding defect

Received September 11, 1990; accepted February 12, 1991.

Correspondence: Robert M. Kliegman, M.D., Division of Neonatology, Rainbow Babies and Childrens Hospital, 2101 Adelbert Road, Cleveland, OH 44106.

Supported by Grant HD-20851 from the National Institute of Child Health and Human Development (R.M.K.), National Institute of Arthritis and Musculoskeletal and Skin Disease Grant AR-32682 (S.D.), and a grant from the Diabetes Association of Greater Cleveland (R.J.P.)

Preliminary data from this study appeared in abstract form in Pediatr Res 25:199A. 1989 of the insulin receptor. Binding defects are manifested by decreased numbers of receptors or decreased affinity of the receptor for insulin. Postreceptor defects may involve transmembrane signaling or intracellular steps distal to the receptor. Skeletal muscle is the organ predominantly responsible for insulin-mediated glucose disposal (4), yet previous studies of insulin receptors in the newborn have focused on rat liver (5) and umbilical cord blood monocytes from human infants (6). Hypertrophy of the cardiac septum has been noted in infants of diabetic mothers (7), suggesting a responsiveness of neonatal cardiac muscle to insulin. There is a single study that evaluates insulin receptors in cardiac muscle (8), but there is no information on skeletal muscle in the newborn.

Previous studies in our laboratory using the euglycemic hyperinsulinemic clamp model have confirmed incomplete suppression of endogenous glucose production and lower rates of total body glucose uptake in response to insulin (9), providing evidence for insulin resistance in the newborn $\mathrm{dog}$. Indirect evidence suggested that this was a postbinding defect.

To further evaluate the possibility of an insulin receptor binding defect as a cause for neonatal insulin resistance, we have studied skeletal muscle, heart, and liver insulin receptors in the newborn dog, using adults as controls. Receptors were analyzed for binding capacity (number of receptors) and affinity of the receptor for insulin.

\section{MATERIALS AND METHODS}

Four adult female beagle dogs and four pregnant beagle dogs were obtained from Marshall Farms (North Rose, NY). Triton X-100 was obtained from Calbiochem (San Diego, CA); wheat germ agglutinin from Vector Labs (Burlingame, CA); SDS from MCB Reagents and HEPES buffer from Research Organics (Cleveland, OH). ${ }^{125}$ I-labeled human insulin $(2000 \mathrm{Ci} / \mathrm{mmol})$ was obtained from Amersham (Arlington Heights, IL) and crystalline porcine insulin from Sigma Chemical Co. (St. Louis, $\mathrm{MO}$ ). All other reagents were obtained from Sigma.

Isolation of tissue. Adult dogs were fasted overnight. After killing by i.v. pentobarbital overdose, liver, skeletal muscle, and cardiac muscle tissue were rapidly removed by gross dissection. The fat-trimmed tissue was freeze-clamped in liquid nitrogen and stored at $-80^{\circ} \mathrm{C}$ until further analysis.

Pregnant dogs were obtained near term (61 d in the beagle) with dates of breeding provided. Impending delivery was confirmed by core temperature decrease, onset of lactation, and/or decreased appetite. Cesarean section under either thorazine or innovar-vet (premixed fentanyl and doperidol) anesthesia given i.v. was performed by a veterinarian. Lidocaine was infiltrated at the incision site. Pups were delivered, and the umbilical cord was clamped, dried, and placed in an Air-Shields incubator (Hatboro, PA) maintained at $30-32^{\circ} \mathrm{C}$. The pups were not fed and were allowed to stabilize for a minimum of $1 \mathrm{~h}$. A $3.5 \mathrm{Fr}$ umbilical Argyle catheter was placed in the umbilical vein for 
administration of pentobarbital euthanasia. Liver, skeletal muscle, and heart tissues were rapidly excised and freeze-clamped in liquid nitrogen. This protocol was approved by the animal investigation committee.

Isolation of insulin receptors. We prepared partially purified, solubilized insulin receptors by modification of the method of Kasuga et al. (10), with approximately $3 \mathrm{~g}$ of liver, skeletal muscle, or heart tissue. Adult and newborn samples were run in parallel. Homogenization was carried out in $50 \mathrm{mM}$ HEPES- 150 $\mathrm{mM} \mathrm{NaCl}$ buffer with $1 \%$ (vol/vol) Triton X-100 at $\mathrm{pH} 7.6$ containing $1 \mathrm{mM}$ bacitracin and the protease inhibitors aprotinin ( 1 trypsin inhibitory unit $/ \mathrm{mL}$ ), $1 \mathrm{mM}$ phenylmethylsulfonyl fluoride, $2 \mathrm{mM}$ leupeptin, and $2 \mathrm{mM}$ pepstatin $\mathrm{A}$ in a Sorvall homogenizer at setting 7 for $2 \mathrm{~min}$. Solubilization was completed by gentle stirring of the homogenate for $90 \mathrm{~min}$ at $4^{\circ} \mathrm{C}$. Centrifugation for $10 \mathrm{~min}$ at $12000 \times g$ at $4^{\circ} \mathrm{C}$ was followed by ultracentrifugation of the supernatant at $150000 \times g$ for $90 \mathrm{~min}$ at $4^{\circ} \mathrm{C}$. Affinity chromatography using lectins has been shown to purify the insulin-binding activity of solubilized membranes as much as 22-fold (11). Approximately $1 \mathrm{~mL}$ of wheat germ agglutinin was added to the supernatant, and equilibration was allowed to occur for $90 \mathrm{~min}$ with gentle shaking at $4^{\circ} \mathrm{C}$. The preparation was then washed with 100 volumes of $50 \mathrm{mM}$ HEPES- $150 \mathrm{mM} \mathrm{NaCl}$ buffer at $\mathrm{pH} 7.6$ with a Triton X-100 concentration of $0.1 \%$ to remove nonspecifically bound protein. Elution from a column was accomplished with $0.3 \mathrm{M}$ N-acetylglucosamine in $50 \mathrm{mM}$ HEPES- $150 \mathrm{mM} \mathrm{NaCl}$ buffer with $0.1 \%$ (vol/vol) Triton X-100 at pH 7.6. Fractions collected were then assayed for protein content by the Bio-Rad protein determination method using $\gamma$-globulin as protein standard. Fractions with protein were pooled, separated into aliquots, and stored at $-80^{\circ} \mathrm{C}$ until further analysis.

Insulin binding. The partially purified insulin receptors were assessed for insulin binding by competition of varying concentrations of porcine insulin with ${ }^{125}$ I-labeled insulin. A final volume of $200 \mu \mathrm{L}$ contained $30 \mu \mathrm{g}$ of eluate protein, $0.05-0.1 \%$ Triton X-100, 0.05-0.2\% BSA (insulin-like and insulinase activity free) in $50 \mathrm{mM}$ HEPES buffer at $\mathrm{pH} 7.6$, approximately $10000 \mathrm{cpm}$ of ${ }^{125} \mathrm{I}$-labeled insulin $(2000 \mathrm{Ci} / \mathrm{mmol})$, and increasing concentrations of cold insulin. Incubation at $4^{\circ} \mathrm{C}$ proceeded overnight. The selective precipitation of the bound insulin and receptor complex by $25 \%$ (wt/vol) polyethylene glycol, using $0.06 \%$ (wt/vol) gamma globulin as the carrier protein, has been modified from Cuatrecases (12). Precipitation was allowed to occur for $20 \mathrm{~min}$ at $4^{\circ} \mathrm{C}$. The pellet was formed using a Beckman microcentrifuge for $10 \mathrm{~min}$. The supernatant was discarded, and $12.5 \%$ (wt/vol) polyethylene glycol was used for an additional wash. The final pellet was formed after a 5-min microcentrifugation, and the supernatant was discarded. The pellets were excised and counted in a Micromedic 4/600 gamma counter. Nonspecific binding controls with labeled and unlabeled insulin were prepared without eluate protein, and the average of these values was subtracted from each sample.

Specific binding percentage was obtained by dividing the sample counts by total number of counts added and multiplying by 100. Scatchard analysis of the bound concentration of ${ }^{125} \mathrm{I}$-insulin and bound/total concentration of ${ }^{125}$ I-insulin was done with a ligand binding computer program (13).

Statistics. Binding was compared between the adult and newborn animal using the paired $t$ test. Affinity and binding capacity were estimated from the binding curves and compared using the paired $t$ test.

\section{RESULTS}

Competition studies were performed in duplicate or triplicate (if adequate tissue available) for each of the partially purified, solubilized receptors from the four animals analyzed. Some tissues were studied twice. Skeletal muscle and heart tissue were pooled from pups of the same litter to obtain adequate tissue for analysis. The newborn and adult tissues compared were run in parallel.

Skeletal muscle. The competition curves of specific ${ }^{125} \mathrm{I}$-insulin binding from the skeletal muscle of adult and newborn dogs are shown in Figure 1. The pooled data demonstrated an increase in specific binding of ${ }^{125}$ I-insulin in the skeletal muscle of newborns compared to the adult. The binding of ${ }^{125} \mathrm{I}$-insulin in the absence of competition from cold insulin (maximal binding) was higher in the newborn skeletal muscle $(9.7 \pm 0.8 \% / 30 \mu \mathrm{g}$ protein, mean \pm SEM) compared to the adult $(4.8 \pm 0.5 \%, p<0.001)$ (Fig. 2). Affinity of the receptor for insulin was compared by determining the concentration of cold insulin needed to reduce maximal binding of ${ }^{125} \mathrm{I}$-insulin by $50 \%$. Newborn skeletal muscle was similar to the adult muscle in binding affinity (Table 1).

Scatchard analysis of the binding data was performed by plotting bound/total versus bound concentration of insulin. These plots are used to derive the number of binding sites and affinity of the receptor for insulin. The insulin receptor showed

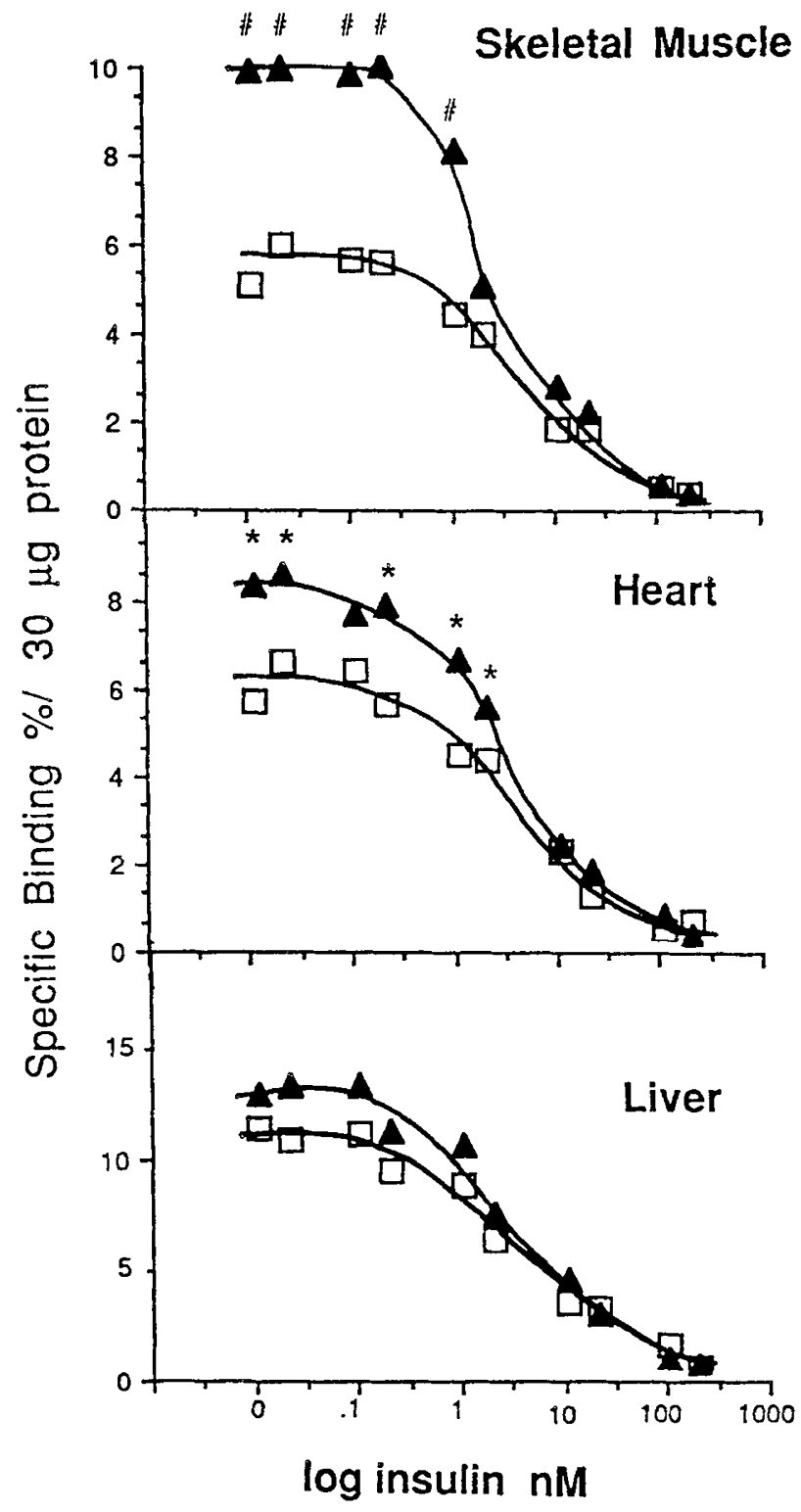

Fig. 1. Comparison of ${ }^{125}$ I-insulin binding to skeletal muscle, heart, and liver in newborn $(\mathbf{\Lambda})$ and adult dogs $(\square)$. Thirty $\mu \mathrm{g}$ of eluate protein from skeletal muscle $(n=10)$, heart $(n=10)$, and liver $(n=13)$ was incubated with ${ }^{125} \mathrm{I}$-insulin and increasing concentrations of unlabeled insulin. The unlabeled insulin concentration is given on the abscissa in a $\log$ scale. The ordinate shows mean percentage of ${ }^{125}$ I-insulin specifically bound. *, paired $p<0.05 ; \#, p<0.001$. 


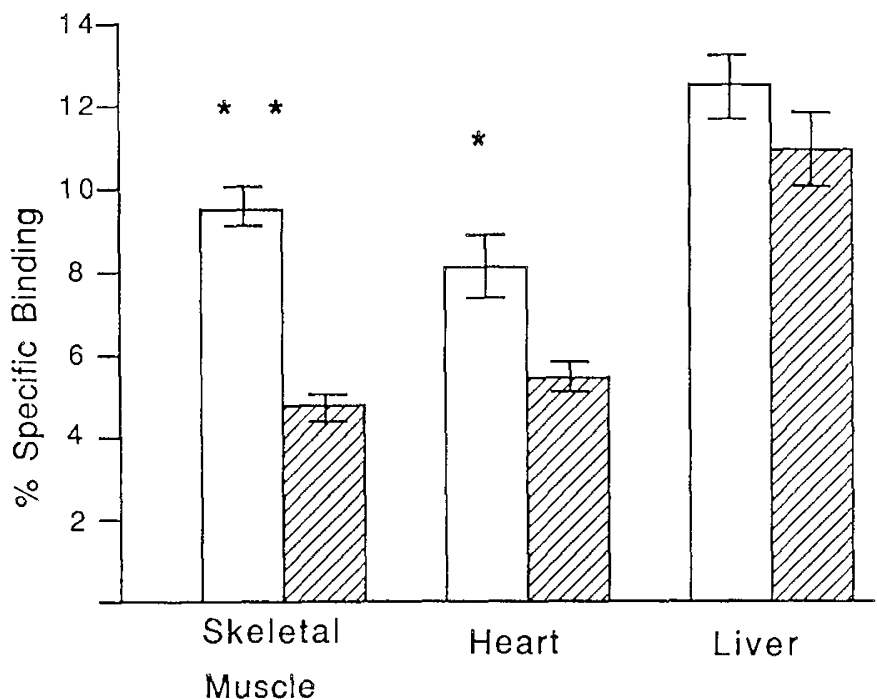

Fig. 2. Comparison of ${ }^{125} \mathrm{I}$-insulin binding to skeletal muscle, heart, and liver in the absence of cold insulin in newborn (open bars) and adult (filled bars) dogs. Mean \pm SEM percentage of ${ }^{25}$ I-insulin specifically bound is shown. *, paired $p<0.05 ;{ }^{* *}, p<0.001$.

Table 1. Characteristics of insulin binding (mean $\pm S E M)^{*}$

\begin{tabular}{|c|c|c|}
\hline & $\begin{array}{l}\text { Concentration of } \\
\text { insulin to decrease } \\
\text { binding by } 50 \% \\
\left(\mathrm{M} \times 10^{-8}\right)\end{array}$ & $\begin{array}{c}\text { Binding capacity } \\
\text { of high-affinity } \\
\text { sites } \\
\left(\mathrm{M} \times 10^{-12}\right)\end{array}$ \\
\hline \multicolumn{3}{|c|}{ Skeletal Muscle } \\
\hline Newborn & $3.08 \pm 1.32$ & $183 \pm 40$ \\
\hline Adult & $3.47 \pm 1.35$ & $120 \pm 29$ \\
\hline \multicolumn{3}{|l|}{ Heart } \\
\hline Newborn & $3.47 \pm 1.32$ & $264 \pm 94$ \\
\hline Adult & $3.47 \pm 1.35$ & $157 \pm 51$ \\
\hline \multicolumn{3}{|l|}{ Liver } \\
\hline Newborn & $3.47 \pm 1.32$ & $230 \pm 29$ \\
\hline Adult & $3.09 \pm 1.41$ & $201 \pm 22$ \\
\hline
\end{tabular}

* High-affinity sites were determined individually by graphic analysis of Scatchard plots (see text). There were Scatchard plots with indeterminate $\mathrm{X}$ intercepts (maximum of two per tissue analyzed) that are not included in the data here; however, the data points are included in the mean Scatchard plots shown in Figure 3. There was no significant difference between pups and adults in the affinity of the receptor for insulin in all tissues studied. An increase in the number of high-affinity sites is noted in skeletal muscle and heart of newborn dogs.

a curvilinear relationship of the Scatchard plot in all tissues studied. This curvilinear line was interpreted as the sum of two intersecting lines representing two populations of receptors, one of high affinity/low capacity and the other of low affinity/high capacity. Pang and Shafer (14) described a linear relationship in Scatchard plots in the physiologic range of insulin, defined as less than $7 \mathrm{nM}$, which encompasses the high affinity/low capacity binding sites. The binding capacity was determined graphically by extrapolating a straight line from the Scatchard plot in the physiologic range for insulin through the $X$ intercept to obtain the concentration of binding sites of high affinity (Fig. 3). Full biologic activity has been shown with $10-40 \%$ receptor occupancy (15), supporting the use of the high-affinity component to estimate receptor number. By this estimation, newborn skeletal muscle contained a greater number of high-affinity receptors $(183 \pm 40 \mathrm{pM}$, mean $\pm \mathrm{SEM})$ when compared to the adult $(120$ $\pm 29 \mathrm{pM}, p<0.002$ ) (Table 1 ). The increased binding of ${ }^{125} \mathrm{I}$ insulin in the newborn skeletal muscle was secondary to increased numbers of high-affinity receptors.

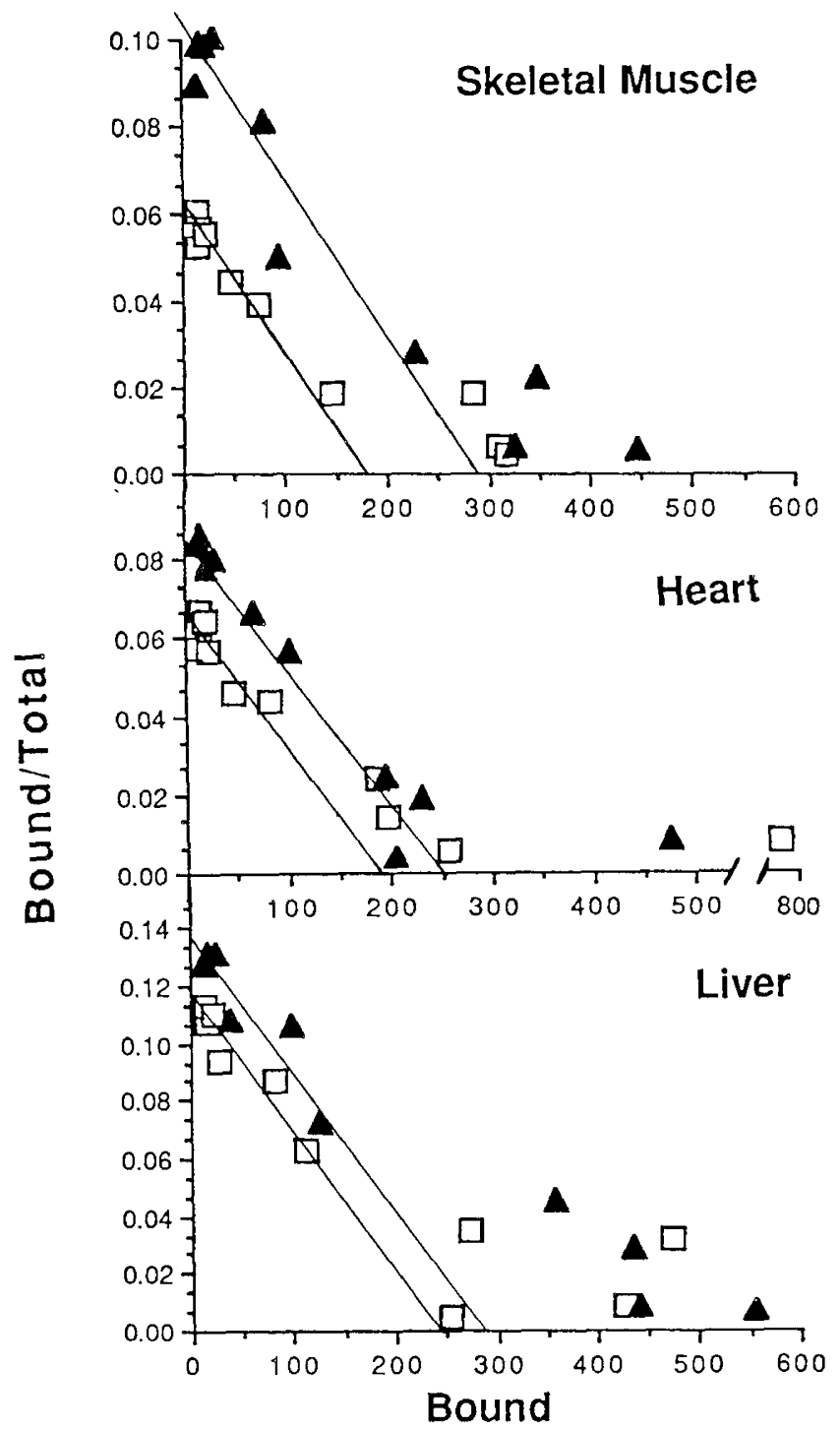

Fig. 3. Scatchard plots of the binding data in Figure 1, in newborn $(\mathbf{\Lambda})$ and adult dogs $(\square)$. Bound/total insulin is plotted $v$ s insulin bound $\left(\mathrm{M} \times 10^{-12}\right)$. The insulin receptor shows a curvilinear relationship in all tissues studied. The high-affinity receptor number is estimated by extrapolating a straight line of the high-affinity/low-capacity portion of the curve through the $\mathrm{X}$ intercept (see text).

Heart. Heart tissues were analyzed in a manner similar to muscle. There was greater binding of ${ }^{125}$ I-insulin in the absence of cold insulin in the newborn heart compared to the adult (8.1 \pm 1.2 versus $5.5 \pm 0.6 \%, p<0.05$ ) (Fig. 2 ). The concentration needed to reduce maximal binding by $50 \%$ was equal to 3.47 $\mathrm{nM}$ for both (Table 1). Scatchard analysis of heart tissues showed increased numbers of high-affinity receptors in the newborn compared to the adult ( $264 \pm 94$ versus $157 \pm 51 \mathrm{pM}, p<0.05$ ) (Table 1).

Liver. There was no difference in binding of ${ }^{125} \mathrm{I}$-insulin between newborn and adult liver $(12.4 \pm 1.5$ versus $10.9 \pm 1.8 \%)$ (Figs. 1 and 2) or concentration of insulin needed to reduce maximal binding by $50 \%$. Binding capacity was also the same between the two groups (Table 1).

\section{DISCUSSION}

Our study demonstrates that the insulin receptors in newborn and adult dog skeletal muscle, heart, and liver are similar in 
affinity for insulin. Specific binding of ${ }^{125} \mathrm{I}$-insulin is increased in skeletal muscle and heart, with increased numbers of highaffinity sites in the newborn compared to the adult tissues. Liver tissue shows no difference in specific binding or numbers of highaffinity sites.

Umbilical cord blood monocytes (6) have increased numbers of binding sites and increased affinity of the receptor for insulin. However, these cells may not reflect the receptor status in other tissues. Rat liver (5) and rat heart (8) also have increased numbers of insulin receptors in the newborn. Our data in newborn dogs showed increased numbers of insulin receptors in heart tissue, but unlike liver from newborn rats, we showed no difference in the liver from newborn dogs compared to the adult. This may be a species difference, or it may reflect the somewhat higher variability seen in our liver tissues. The neonatal tissues examined in earlier studies and the current investigation of newborn dogs are consistent and suggest that numbers and affinity of the insulin receptor are not limiting factors in neonatal insulin responsiveness.

Insulin resistance has been previously investigated in our laboratory using the euglycemic hyperinsulinemic clamp technique in newborn and adult dogs. Newborn dogs did not consistently suppress endogenous glucose production and never achieved maximal glucose metabolization in the presence of hyperinsulinemia when compared with adult dogs (9). These studies indicated that insulin resistance in the newborn dog occurred in the liver (continued glucose production) and skeletal muscle (reduced glucose metabolization). The inability to achieve maximal effect despite high concentrations of insulin indirectly suggested a postbinding defect (15). Our data confirm that insulin resistance is not related to an insulin-binding defect in liver from the newborn dog, which is consistent with the data from newborn rats. We extended the studies from rats and demonstrated that skeletal muscle from newborn dogs does not have a defect in the number of insulin receptors or their affinity to insulin and confirmed a postbinding defect in newborn insulin resistance.

Insulin action has been correlated with phosphorylation of tyrosine residues in the $\beta$-subunit of the receptor $(16,17)$ and translocation of glucose transporter proteins from an intracellular storage pool to the plasma membrane (18). Insulin resistance secondary to a postbinding defect may be at the level of insulinstimulated phosphorylation (receptor tyrosine kinase activity) (19) or steps distal to the receptor. Adults with noninsulindependent diabetes have shown decreased tyrosine kinase activity in red cells (20), fat (19), liver (21), and skeletal muscle (22), as well as decreased numbers of glucose transporters in adipocytes (23). Tyrosine kinase activity has been investigated by Sinha and Jenquin (24) in neonatal rat liver. Insulin-stimulated tyrosine kinase activity was the same in neonatal compared to adult liver after correction for the increased insulin binding.

We are unaware of any information regarding tyrosine kinase activity or glucose transporters in the skeletal muscle of the newborn. The newborn dog may serve as a good animal model for the evaluation of postbinding steps in insulin action including tyrosine kinase activity and glucose transporters.
Acknowledgments. The authors thank Joyce Nolan, Cassandra Blythewood, and Mary Shively for assistance in the preparation of this manuscript.

\section{REFERENCES}

1. Cowett R, Szech M, Susa J, Schwartz R 1980 Blunted muscle responsiveness to insulin in the neonatal rat. Metabolism 29:563-567

2. Goldman S, Hirata T 1980 Attenuated response to insulin in very low birthweight infants. Pediatr Res 14:50-53

3. Pildes R 1986 Neonatal hyperglycemia. J Pediatr 109:905-907

4. DeFronzo R, Jequier J, Maeder E, Wahren J, Felber J 1981 The effect of insulin on the disposal of intravenous glucose: results from indirect calorimetry and hepatic and femoral venous catheterization. Diabetes 30:1000-1007

5. Sinha MK, Jenquin M 1987 Subunit structure, autophosphorylation, and tyrosine-specific protein kinase activity of hepatic insulin receptors in fetal, neonatal and adult rats. Diabetes 36:1161-1166

6. Thorsson AV, Hintz RL 1977 Insulin receptors in the newborn: increase in receptor affinity and number. N Engl J Med 297:908-912

7. Gutgell MP, Speer ME, Rosenberg HS 1980 Characterization of the cardiomyopathy in infants of diabetic mothers. Circulation $60: 441-450$

8. Steven J, Whitsett JA 1979 Insulin binding to neonatal human, guinea pig and rat myocardial membranes. Pediatr Res 13:482(abstr)

9. Kliegman R, Trindade C, Huang M, Hulman S 1989 Effects of euglycemic hyperinsulinemia on neonatal canine hepatic and muscle metabolism. Pediatr Res 25:124-129

10. Kasuga M, Zick Y, Blithe DL, Crettaz M, Kahn CR 1982 Insulin stimulates tyrosine phosphorylation of the insulin receptor in a cell free system. Nature 298:667-669

11. Hedo JA, Harrison LC, Roth J 1981 Binding of insulin receptors to lectins: evidence for cornmon carbohydrate determinants on several membrane receptors. Biochem 20:3385-3393

12. Cuatrecases P 1972 Properties of insulin receptor isolated from liver and fat cell membranes. J Biol Chem 247:1980-1991

13. Munson PA, Rodbard D 1980 LIGAND. A versatile computerized approach for characterization of ligand-binding systems. Anal Biochem 107:220-239

14. Pang DT, Shafer JA 1984 Evidence that insulin receptor from human placenta has a high affinity for only one molecule of insulin. J Biol Chem 259:85898598

15. Rizza RA, Mandarino LJ, Gerich JE 1981 Mechanisms of insulin resistance in man: assessment using the insulin dose-response curve in conjunction with insulin-receptor binding. Am J Med 70:169-176

16. Kasuga M, Zick Y. Blith DL, Karlsson FA, Haring MU, Kahn CR 1982 Insulin stimulation of the beta subunit of the insulin receptor. J Biol Chem 257:9891-9894

17. Pang DT, Sharma BR, Shafer JA, White MF, Kahn CR 1985 Predominance of tyrosine phosphorylation of insulin receptors during the initial response of intact cells to insulin. J Biol Chem 260:7131-7136

18. Thorens B, Charron MJ, Lodish HF 1990 Molecular physiology of glucose transporters. Diabetes Care 13:209-218

19. Freidenburg GR, Henry RR, Klein HH, Riechert DR, Olefsky JM 1987 Decreased kinase activity of insulin receptors from adipocytes of non-insulindependent diabetic subjects. J Clin Invest 79:240-250

20. Comi RJ, Grunberger G, Gordon P 1987 Relationship of insulin binding and insulin-stimulated tyrosine kinase activity is altered in type Il diabetes 1987 J Clin Invest 79:453-462

21. Caro JF, Itoop O, Pories WJ, Meelheim D, Flickinger EG, Thomas F, Jenquin M, Silverman JF, Khazanie PG, Sinha MK 1986 Studies on the mechanism of insulin resistance in the liver from humans with non-insulin-dependent diabetes. J Clin Invest 78:249-258

22. Arner $\mathrm{P}$, Pollare $T$, Lithell $H$, Livingston $\mathrm{IN} 1987$ Defective insulin receptor kinase in human skeletal muscle in obesity and type II (non-insulin-dependent) diabetes mellitus. Diabetologia 30:437-440

23. Garvey WT, Huecksteadt TP, Matthaei S, Olefsky JM 1988 Role of glucose transporters in the cellular insulin resistance of type II non-insulin-dependent diabetes mellitus. J Clin Invest 81:1528-1536

24. Sinha MK, Jenquin M 1987 Subunit structure autophosphorylation, and tyrosine-specific protein kinase activity of hepatic insulin receptors in fetal, neonatal and adult rats. Diabetes 36:1161-1166 